\title{
LARVICIDAL AND ANTIFEEDANT ACTIVITIES OF CLOVE LEAF OIL AGAINST Spodoptera litura (F.) ON SOYBEAN
}

\author{
Riska Nur Fateha, Maria Grasela, Muhammad Nur Ichwan, Eny Wahyuning Purwanti, \& \\ Irianti Kurniasari \\ Sustainable Agricultural Extension Program, Politeknik Pembangunan Pertanian Malang, Indonesia \\ Jl. Dr. Cipto 144A Bedali Lawang Malang \\ E-mail: kurnia_saree@yahoo.com
}

Manuscript received: 21 August 2020. Revision accepted: 12 October 2020.

\begin{abstract}
Larvicidal and antifeedant activities of clove leaf oil against Spodoptera litura (F.) on Soybean. Economic losses due to infestation by the soybean armyworm, Spodoptera litura can reach up to $100 \%$. Some farmers often used insecticide to control the armyworm. However, regular use of insecticide can cause several negative effects such as environmental pollution, residual toxicity, and health hazard for human. The objective of this research was to determine the larvicidal, antifeedant, and activities of clove leaf oil (CLO) against the armyworm S. litura on soybean. The research was carried out at the plant pest control laboratory of Politeknik Pembangunan Pertanian Malang. Clove leaf oil was evaluated for its larvicidal and antifeedant activities against ten third instar larvae of the armyworm. Completely randomized design was used with concentration levels of CLO as treatments. i.e. $0.4,0.5,0.67,1.0$, and $2.0 \%$ by volume. Profenofos $500 \mathrm{~g} \mathrm{~L}^{-1} 0.1 \%$ and distilled water were include as control. Each treatment consisted of five replications. Mortality of the larvae and antifeedant activity were analyzed using analysis of variance, followed by probit analysis for calculating $\mathrm{LC}_{50}$ and $\mathrm{LT}_{50}$. The results showed that CLO at $2.0 \%$ concentration was the most effective with regard to larvicidal and antifeedant activities. The $\mathrm{LC}_{50}$ of CLO was $0.09 \%$ with $\mathrm{LT}_{50} 24.6$ hours. This study revealed that the environmentally friendly CLO can be used as an alternative to synthetic insecticide for control S. litura.
\end{abstract}

Key words: antifeedant activity, botanical insecticede, clove leaf oil, mortality, Spodoptera litura

\section{INTRODUCTION}

The soybean armyworm, Spodoptera litura (F.), is one of major pests causing yield losses on soybean in many regions in Indonesia including East Java (Tengkano $\&$ Suharsono, 2005). The yield losses due to the armyworm infestation was depend on the insect population level, insect development phase, growth phase and soybean varieties. In the vegetative stage, young instar (1-3) eat the leaves leaving the upper layers epidermis and leaf bones, while the old instar (4-6) eat the whole leaves. In the generative stage, armyworm attacks young soybean pods (Marwoto \& Suharsono, 2008; Fattah \& Ilyas, 2016). The integrated methods to control $S$. litura is needed, including using plant base insecticide.

Plant base insecticides is eco-friendly, it's not resulting negative impact on human health, environmental contamination such as insecticide resistance, pest resurgence, residue in plant, and death effects of nontarget organisms (pollinating insects, natural enemies, and parasitoids) (Jeyasankar et al., 2014; Javier-Hila et al., 2017). Biological control by using botanical insecticide has been compatible to other strategies such as using resistant variety, soil management, intercropping and so on (Rajashekar et al., 2012).

Clove (Syzygium aromaticum) is one of the plants that have been identified as a botanical insecticide in Indonesia. Cloves produce secondary metabolites as potential active ingredients that are used to controlling insect pests. Based on its activities against insects, botanical insecticides can be classified into six groups: repellents, feeding deterrents/antifeedants, toxicants, growth retardants, chemosterilants, and attractants (Rajashekar et al., 2012; Hikal et al., 2017). The main active ingredient in clove leave oil is eugenol (80-88\%) that was effective against various insect pests such as cabbage caterpillar (Crocidolomia pavonana) (Rismayani \& Laba, 2015), pear psylla (Cacopsylla chinensis) (Tian et al., 2015), mealworm beetle (Tenebrio molitor) (Martínez et al., 2018), maize armyworm (Spodoptera frugiperda) (Vargas-méndez 
et al., 2019), and cowpea weevil (Callosobruchus maculatus) (Armijos et al., 2019). The other components are eugenol acetate and caryophylene (Nurdjannah \& Bermawie, 2012). Eugenol gives a strong contact toxicity that can be used as a powerful insecticide with other anti-insect effect such as antifeedants to control armyworm on soybean. The objective of this research was to determine the larvicidal and antifeedant activity of clove leaf oil against soybean armyworm.

\section{MATERIALS AND METHODS}

Research Site. This research was conducted from July to August 2018 at the Plant Pest Control laboratory of Politeknik Pembangunan Pertanian Malang. A preliminary test was carried out with concentrations of $1.0,2.0,3.0$, and $4.0 \%$ with feed dyeing and spraying method. Feed dyeing used to measure the antifeedant effect. In the preliminary test it was known that within 9 min after CLO application larval mortality has been noted at the $2.0 \%$ concentration. In the leaves treated with the feed dyeing method no part of the leaves were eaten by the larvae because the leaves were damaged by oxidation. The preliminary test was continued with the definitive test of CLO using spraying method at the following concentrations as treatments: $0.4,0.5,0.67$, 1.0 , and $2.0 \%$.

Experimental Design. This research was arranged in a completely randomized design with seven treatments and five replications. Treatments used in this study were five levels of CLO concentration, i.e. 0.4, 0.5, 0.67, 1.0, and $2.0 \%$ and two additional treatmens, i.e. (profenofos $500 \mathrm{~g} \mathrm{~L}^{-1} 0.1 \%$ and distilled water) as controls.

Preparation of Clove Leaf Oil. Clove leaf oil prepared by steam distillation was obtained from a home industry in Sugihwaras village Kediri Regency. CLO $(1 \mathrm{~mL})$ was emulsified with $1 \mathrm{~mL} \mathrm{NaOH}$ and then diluted with distilled water to the desired volume at different concentrations. Profenofos $500 \mathrm{~g} \mathrm{~L}^{-1}$ as a positive control was dissolved with distilled water $1 \mathrm{~mL} \mathrm{~L}^{-1}$. Each solution was put into separate spray bottles in $1 \mathrm{~L}$ volume.

Rearing of Spodoptera litura. Third instar larvae of $S$. litura were obtained from the offspring of imago reared in Balai Penelitian Tanaman Pemanis dan Serat (Balittas) Malang. In this study, third instar larvae of $S$. litura were used because the larvae at this stage feed gregariously and cause considerable damages (Priyanka \& Srivastava, 2012; Hasibuan et al., 2019). The larvae were fed soybean leaves obtained from soybean plants that was grown in polybags and kept in plastic jars which were placed in laboratory room temperature.

Larvicidal Activity. A piece of soybean leaf was placed in a petridish followed by ten third instar larvae of S. litura. Spraying of the treatment solution was directed on the leaf by handsprayer approximately $50 \mathrm{~mL}$ for each leaf or until its wet thoroughly. The spraying method used in this study simulated the application carried out by farmer in the field. Treated leaves were replenished every day until day 3 . The number of dead larvae was observed every $12 \mathrm{~h}$ for $72 \mathrm{~h}$. The larvae were considered dead when they did not respond to a mild touch and became soft and blackened.

Antifeedant Activity. The procedure of treatments was the same as in the larvicidal activity assays. The leaf area consumed by the test larvae in various treatments with no-choices method and controls was estimated using graph sheet paper every $12 \mathrm{~h}$ for $72 \mathrm{~h}$. Antifeedant activity of clove leaf oil was calculated based on the antifeedant index (AFI). The AFI was calculated by correcting the consumption of treated leaves $(\mathrm{T})$ with the consumption of control leaves (C) as follows (Jeyasankar et al., 2014):

$$
\mathrm{AFI}=1-\frac{\mathrm{T}}{\mathrm{C}} \times 100 \%
$$

Data Analysis. Data were analyzed with one-way analysis of variance using SPSS 20 and significant difference between treatments were analyzed using Duncan's multiple range test at 0.05 significance level. The percentage of larval mortality analyzed by probit analysis method to determine $\mathrm{LC}_{50}$ and $\mathrm{LT}_{50}$ (Tian et al., 2015).

\section{RESULTS AND DISCUSSION}

Larvicidal Activity. There was mortality in the larvae that treated with profenofos $500 \mathrm{~g} \mathrm{~L}^{-1}$ and CLO, whereas in the distilled water as a negative control there was no mortality. The result showed that CLO treatment was able to kill $S$. litura larvae at $12 \mathrm{~h}$ after treatment, indicated that CLO has ability to kill larvae quickly. Dayan et al. (2009) stated that eugenol as active ingredients in CLO is a fast acting contact insecticide that is effective on some plant pests such as armyworms. The statistical analysis showed that, in the end observation ( $72 \mathrm{~h}$ observation) the treatment of profenofos $500 \mathrm{~g} \mathrm{~L}^{-1} 0.1 \%(\mathrm{P} 1)$ had the highest number of larval mortalities followed by CLO treatments with 
concentration $2.0 \%(\mathrm{P} 2), 1.0 \%(\mathrm{P} 3), 0.67 \%$ (P4), $0.5 \%$ (P5), and $0.4 \%(\mathrm{P} 6)$ (Table 1). In addition, the mortality of larvae increased with the time. There was no significantly difference between $\mathrm{P} 1$ and $\mathrm{P} 2$ treatment in the $24 \mathrm{~h}$ until $72 \mathrm{~h}$ of observation, indicated that CLO was considered to be used as an alternative for synthetic pesticides.

The visual observation showed that the treated third instar larvae of $S$. litura by CLO had changed their body characteristics, they body turned into black, limp, and soft (Figure 1). The symptoms were likely due to the act of eugenol as active ingredients in CLO. The spraying method simultaneously between soybean leaves and larvae in the larvicidal assay make it possible for CLO can enter the armyworm body via the respiratory system (inhalation poison), cuticle (contact poison), and digestive system (stomach poison) (Saad et al., 2018). The presence of eugenol may be responsible for neurotoxic and cytotoxic effect which influence in insect respiration. The act of eugenol in the nervous system are by inhibiting AChe and GABA receptor causing convulsion symptoms (stressful wiggling and paralysis) (Waliwitiya, 2005; Mossa, 2016; Jumbo et al., 2018). Eugenol are potent inhibitor cellular energy production, after they are in contact or enter the insect body. In the mitochondrial insect, they are inhibiting NADH resulting ATP deprivation. At the end, cell respiration will be stopped due to the lack of energy led to the death of larvae (Retnasari et al., 2017; Mondal et al., 2018).

From $\mathrm{LC}_{50}$ and $\mathrm{LT}_{50}$ regression equation showed that in each addition $0.2 \%$ of the CLO concentration would increase mortality of S.litura larvae by $2.46 \%$ and $12 \mathrm{~h}$ additional time would increase mortality of S.litura larvae by $3.48 \%$ (Figure $2 \& 3$ ). Clove oil in essential oil formula has $\mathrm{LC}_{50} 0.5 \mathrm{mg} \mathrm{L}^{-1}$ again Artemia salina (Cansian et al., 2017). From the coefficient of determination $\left(\mathrm{R}^{2}\right)$ showed that the mortality of $S$. litura larvae influenced by the level of CLO concentration and time of application and both of them influenced each other by $84.65 \%$ and $99,13 \%$, respectively. The coefficient was positive, it means that the longer time after application would increase the mortality of $S$. litura larvae and there was strong relationship between time and mortality rate of $S$. litura larvae.

Antifeedant Activity. The result showed that the application of CLO with high concentration having a high AFI index. This phenomenon can be inferred from Table 2. At $48 \mathrm{~h}$ until $72 \mathrm{~h}$ of observation after treatment, CLO treatment had the same effect and showed there was no significantly difference in all concentration with profenofos $500 \mathrm{~g} \mathrm{~L}^{-1} 0.1 \%$ treatment. The presence of eugenol in CLO makes the treated leaves having a strong

Table 1. Larvicidal activity of clove leave oil against third instar larvae of S. litura

\begin{tabular}{ccccccc}
\hline Treatment & \multicolumn{5}{c}{ Average number of the dead larvae per 12 h of observation (larvae) } \\
\cline { 2 - 7 } & \multicolumn{1}{c}{12} & 24 & 36 & 48 & 60 & 72 \\
\hline P1 & $8.20 \pm 1.64 \mathrm{~d}$ & $9.80 \pm 0.44 \mathrm{e}$ & $10.00 \pm 0 \mathrm{~d}$ & $10.00 \pm 0 \mathrm{~d}$ & $10.00 \pm 0 \mathrm{~b}$ & $10.00 \pm 0 \mathrm{~b}$ \\
P2 & $4.20 \pm 3.89 \mathrm{c}$ & $9.20 \pm 1.09 \mathrm{e}$ & $10.00 \pm 0 \mathrm{~d}$ & $10.00 \pm 0 \mathrm{~d}$ & $10.00 \pm 0 \mathrm{~b}$ & $10.00 \pm 0 \mathrm{~b}$ \\
P3 & $2.40 \pm 0.89 \mathrm{abc}$ & $5.20 \pm 2.38 \mathrm{~cd}$ & $7.80 \pm 1.09 \mathrm{~cd}$ & $9.00 \pm 0.70 \mathrm{~cd}$ & $9.80 \pm 0.44 \mathrm{~b}$ & $10.00 \pm 0 \mathrm{~b}$ \\
P4 & $1.00 \pm 1.00 \mathrm{ab}$ & $2.20 \pm 1.09 \mathrm{~b}$ & $4.20 \pm 2.86 \mathrm{~b}$ & $5.80 \pm 2.38 \mathrm{~b}$ & $8.40 \pm 0.54 \mathrm{~b}$ & $9.80 \pm 0.44$ \\
P5 & $3.60 \pm 2.07 \mathrm{bc}$ & $6.20 \pm 1.64 \mathrm{~d}$ & $7.60 \pm 2.07 \mathrm{~cd}$ & $8.80 \pm 1.64 \mathrm{~cd}$ & $9.20 \pm 1.78 \mathrm{~b}$ & $9.60 \pm 0.89$ \\
P6 & $1.80 \pm 1.78 \mathrm{abc}$ & $3.60 \pm 1.81 \mathrm{bc}$ & $5.60 \pm 2.60 \mathrm{bc}$ & $7.40 \pm 2.60 \mathrm{bc}$ & $8.20 \pm 2.94 \mathrm{~b}$ & $9.40 \pm 0.89$ \\
P7 & $0 \mathrm{a}$ & $0 \mathrm{a}$ & $0 \mathrm{a}$ & $0 \mathrm{a}$ & $0 \mathrm{a}$ & $0 \mathrm{a}$ \\
\hline
\end{tabular}

Remarks: Average of five replications. Values in the same column followed by the same letter are not significantly different at $95 \%$ test level. $\mathrm{P} 1=$ Profenofos $500 \mathrm{~g} \mathrm{~L}^{-1} 0.1 \% ; \mathrm{P} 2=$ Clove leave oil concentracion $2.0 \% ; \mathrm{P} 3=1.0 \%$; $\mathrm{P} 4=0.67 \% ; \mathrm{P} 5=0.5 \% ; \mathrm{P} 6=0.4 \% ; \mathrm{P} 7=$ distilled water.

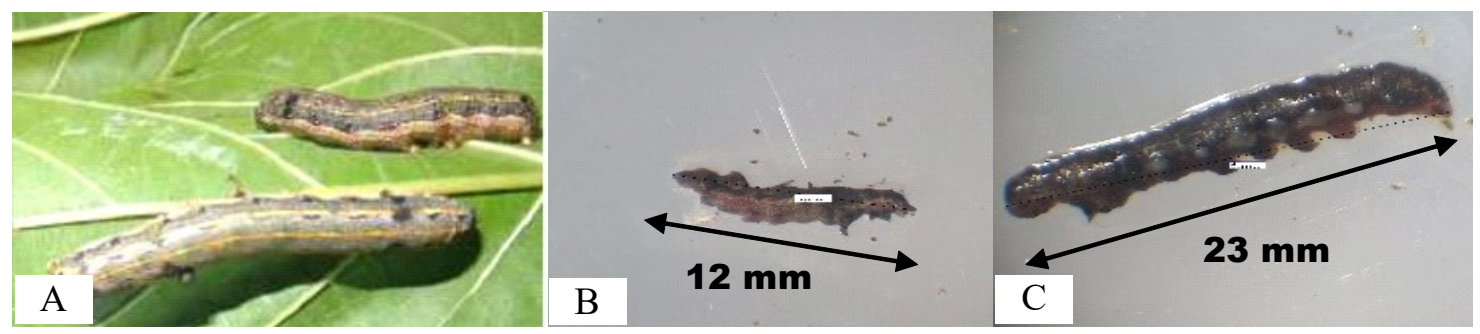

Figure 1. (A) Non-treated (Fattah \& Ilyas, 2016); (B) treated with profenofos $500 \mathrm{~g} \mathrm{~L}^{-1}(\mathrm{M}=35 \times)$; (C) treated with clove leave oil $(\mathrm{M}=35 \times)$, the larvae become soft and black. 
odor thus inhibit the insect feeding. According to Mossa, (2016) antifeedant are compounds or substances that reduce insect feeding by rendering the treated materials unattractive or unpalatable. This substance inhibits or disrupt insect feeding by modification the insect behavior, through a direct action on peripheral sensilla of insects (Cansian et al., 2017).

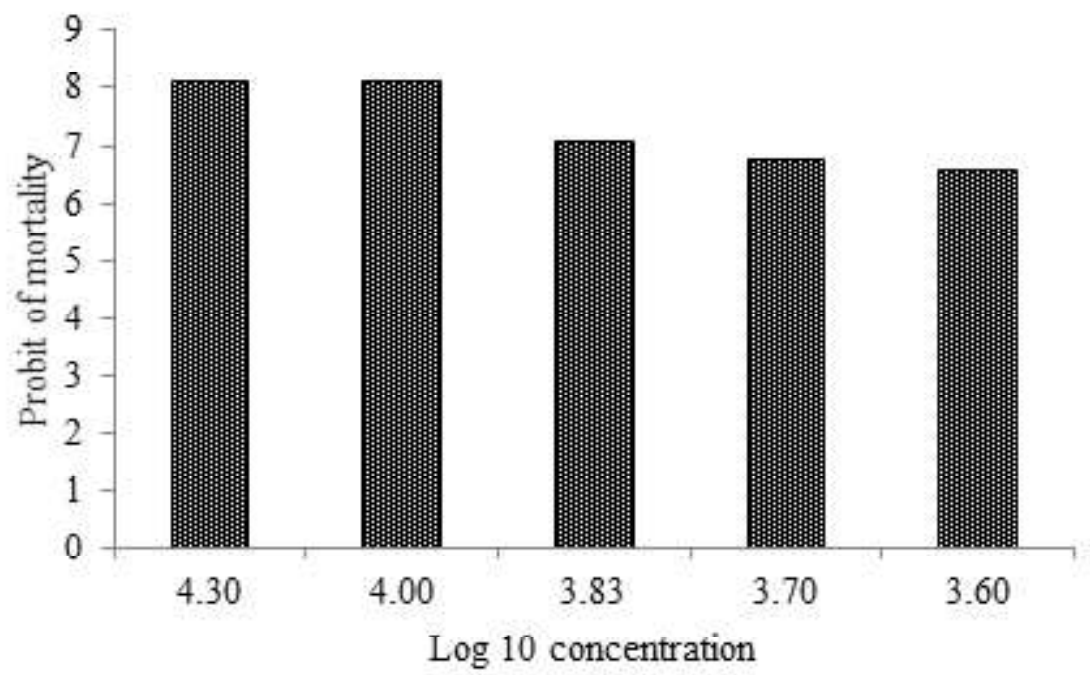

Figure 2. Regression analysis the effect of concentrations on mortality of S. litura larvae.

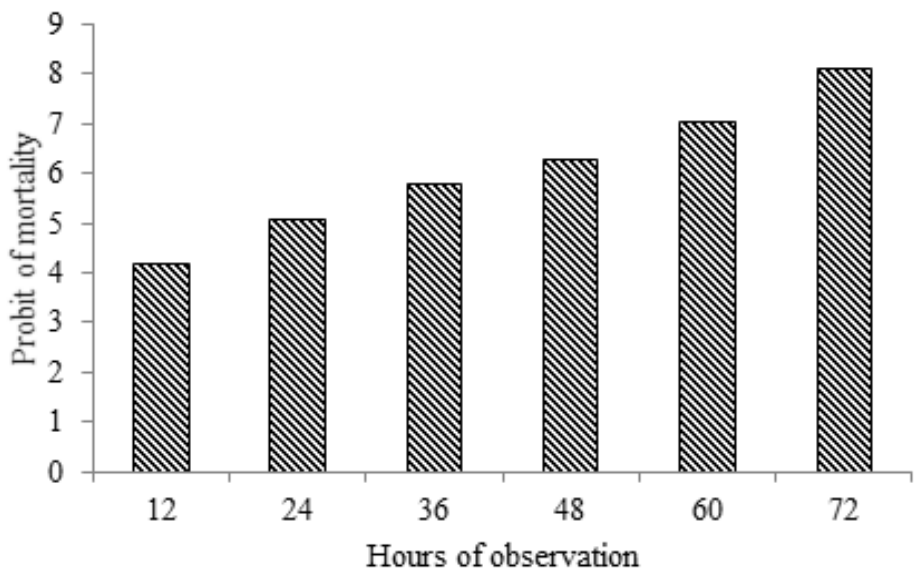

Figure 3. Regression analysis the effect of time on mortality of $S$. litura larvae.

Table 2. Antifeedant activity of clove leave oil against third instar larvae of $S$. litura

\begin{tabular}{cllllll}
\hline \multirow{2}{*}{ Treatment } & \multicolumn{5}{c}{ Average percentage of antifeedant index (AFI) per 12 h of observation (\%) } \\
\cline { 2 - 7 } & \multicolumn{1}{c}{12} & \multicolumn{1}{c}{24} & \multicolumn{1}{c}{36} & \multicolumn{1}{c}{48} & \multicolumn{1}{c}{60} & \multicolumn{1}{c}{72} \\
\hline P1 & $91.20 \pm 3.58 \mathrm{~d}$ & $100 \pm 0 \mathrm{c}$ & $100 \pm 0 \mathrm{c}$ & $100 \pm 0 \mathrm{~b}$ & $100 \pm 0 \mathrm{~b}$ & $100 \pm 0 \mathrm{~b}$ \\
P2 & $80.50 \pm 12.90 \mathrm{~cd}$ & $93.20 \pm 6.74 \mathrm{bc}$ & $88.80 \pm 12.21 \mathrm{c}$ & $100 \pm 0 \mathrm{~b}$ & $100 \pm 0 \mathrm{~b}$ & $100 \pm 0 \mathrm{~b}$ \\
P3 & $66.80 \pm 10.47 \mathrm{bc}$ & $87.90 \pm 6.71 \mathrm{ab}$ & $63.80 \pm 6.49 \mathrm{~b}$ & $98.80 \pm 1.96 \mathrm{~b}$ & $97.50 \pm 5.59 \mathrm{~b}$ & $97.50 \pm 5.59 \mathrm{~b}$ \\
P4 & $68.40 \pm 10.70 \mathrm{bc}$ & $85.70 \pm 16.05 \mathrm{ab}$ & $62.40 \pm 27.43 \mathrm{~b}$ & $97.20 \pm 2.97 \mathrm{~b}$ & $86.90 \pm 8.10 \mathrm{~b}$ & $81.40 \pm 19.22 \mathrm{~b}$ \\
P5 & $65.10 \pm 20.47 \mathrm{bc}$ & $87.10 \pm 8.44 \mathrm{ab}$ & $60.60 \pm 20.09 \mathrm{~b}$ & $94.70 \pm 11.85 \mathrm{~b}$ & $86.40 \pm 30.45 \mathrm{~b}$ & $97.90 \pm 4.69 \mathrm{~b}$ \\
P6 & $55.60 \pm 14.53 \mathrm{~b}$ & $85.90 \pm 4.99 \mathrm{ab}$ & $45.80 \pm 19.15 \mathrm{ab}$ & $95.80 \pm 4.52 \mathrm{~b}$ & $80.20 \pm 26.91 \mathrm{~b}$ & $77.80 \pm 34.60 \mathrm{~b}$ \\
P7 & $28.10 \pm 12.77 \mathrm{a}$ & $79.20 \pm 10.22 \mathrm{a}$ & $29.80 \pm 27.63 \mathrm{a}$ & $51.50 \pm 20.44 \mathrm{a}$ & $36.70 \pm 29.06 \mathrm{a}$ & $34.30 \pm 22.69 \mathrm{a}$ \\
\hline
\end{tabular}

Remarks: Average of five replications. Values in the same column followed by the same letter are not significantly different at $95 \%$ test level. $\mathrm{P} 1=$ profenofos $500 \mathrm{~g} \mathrm{~L}^{-1} 0.1 \%$; $\mathrm{P} 2=$ clove leave oil concentracion $2.0 \%$; $\mathrm{P} 3=1.0 \%$; $\mathrm{P} 4=0.67 \% ; \mathrm{P} 5=0.5 \% ; \mathrm{P} 6=0.4 \% ; \mathrm{P} 7=$ distilled water. 


\section{CONCLUSION}

CLO exhibited potential larvicidal and antifeedant activity at high concentration against third instar larvae of $S$. litura. In this study revealed that CLO can be used as an alternative to synthetic pesticides. Based on the $\mathrm{LC}_{50}$ and $\mathrm{LT}_{50}$ approaches, the concentration of CLO were $0.09 \%$ in $24.6 \mathrm{~h}$.

\section{ACKNOWLEDGMENTS}

The authors would like to thank Politeknik Pembangunan Pertanian Malang for funding support and to Mrs. Niken Rani Wandansari, SP. MP for her guidance in statistical analysis.

\section{REFERENCES}

Armijos MJG, Jumbo LOV, Faroni LRD, Oliveira EE, Flores AF, Heleno FF, \& Haddi K. 2019. Fumigant toxicity of eugenol and its negative effects on biological development of Callosobruchus maculatus L. Revista de Ciencias Agrícolas. 36(1): 5-15.

Cansian RL, Vanin AB, Orlando T, Piazza SP, Puton BMS, Cardoso RI, Gonçalves IL, Honaiser TC, Paroul N, \& Oliveira D. 2017. Toxicity of clove essential oil and its ester eugenyl acetate against Artemia salina. Braz. J. Biol. 77(1): 155-161.

Dayan FE, Cantrell CL, \& Duke SO. 2009. Natural products in crop protection. Bioorg. Med. Chem. 17(12): 4022-4034.

Fattah A \& Ilyas A. 2016. Siklus hidup ulat grayak (Spodoptera litura, F) dan tingkat serangan pada beberapa varietas unggul kedelai di Sulawesi Selatan. In: Pramesti AD, Kurniawan H, Syarif M, \& Ansari MI (Eds.). pp. 834-842. Prosiding Seminal Nasional Inovasi Teknologi Pertanian. Balai Besar Pengkajian dan Pengembangan Teknologi Pertanian.

Hasibuan R, Purnomo, Wibowo L, Izzaturrijal, \& Lumbanraja J. 2019. Comparative bioactivity of plant extracts and synthetic insect growth regulators against Spodoptera litura (F.) (Lepidoptera: Noctuidae). J. HPT Tropika. 19(2): 118-126.

Hikal WM, Baeshen RS, \& Said-Al Ahl HAH. 2017. Botanical insecticide as simple extractives for pest control. Cogent Biol. 3(1): 1-16.
Javier AMV, Ocampo VR, Ceballo FA, \& Javier PA. 2017. Insecticidal activity of selected essential oil extracts against common cutworm, Spodoptera litura Fabricius (Lepidoptera: Noctuidae). Philipp. J. Sci. 146(3): 247-256.

Jeyasankar A, Premalatha S, \& Elumalai K. 2014. Antifeedant and insecticidal activities of selected plant extracts against Epilachna beetle, Henosepilachna vigintioctopunctata (Coleoptera: Coccinellidae). AE. 2(1): 14-19.

Jumbo LOV, Haddi K, Faroni LRD, Heleno FF, Pinto FG, \& Oliveira EE. 2018. Toxicity to, oviposition and population growth impairments of Callosobruchus maculatus exposed to clove and cinnamon essential oils. PLoS ONE. 13(11): e0207618.

Martínez LC, Plata-Rueda A, Colares HC, Campos JM, Santos MHD, Fernandes FL, Serrão JE, \& Zanuncio JC. 2018. Toxic effects of two essential oils and their constituents on the mealworm beetle, Tenebrio molitor. Bull. Entomol. Res. 108(6): 716-725.

Marwoto \& Suharsono. 2008. Strategi dan komponen teknologi pengendalian ulat grayak (Spodoptera litura Fabricius) pada tanaman kedelai. Jurnal Litbang Pertanian. 27(4): 131-136.

Mondal P, Biswas S, Pal K, \& Ray DP. 2018. Annona squamosa as a potential botanical insecticide for agricultural domains: a review. IJBS. 5(1): 8189.

Mossa ATH. 2016. Green pesticides: essential oils as biopesticides in insect-pest management. $J$. Environ. Sci. Technol. 9(5): 354-378.

Nurdjannah N \& Bermawie N. 2012. Cloves. In: Peter KV (Ed.). Handbook of Herbs and Spices. pp. 197-215. Woodhead Publishing Ltd, Abington Cambridge England.

Priyanka B \& Srivastava R. 2012. Larvicidal and growth regulatory activities of some essential oils against Asian army worm, Spodoptera litura (Fab.). J. Biopestic. 5(2): 186-190.

Rajashekar Y, Bakthavatsalam N, \& Shivanandappa T. 2012. Botanicals as grain protectants. Psyche. 2012: 646740 .

Retnasari E, Puspasari LT, Meliansyah R, Maharani R, Hidayat Y, \& Dono D. 2017. Toxicity of Barringtonia asiatica L. (KURZ.), Melia 
azedarach L. and Annona muricata L. seed extract mixture against larvae Crocidolomia pavonana F. (Lepidoptera: Pyralidae). KnE. Life Sciences. 2(6): 246-255.

Rismayani \& Laba IW. 2015. The effectivity of citronella and clove oils against cabbage caterpillar Crocidolomia pavonana. Bul. Littro. 26(2): 109-116.

Saad MMG, Abou-Taleb HK, \& Abdelgaleil SAM. 2018. Insecticidal activities of monoterpenes and phenylpropenes against Sitophilus oryzae and their inhibitory effects on acetylcholinesterase and adenosine triphosphatases. Appl. Entomol. Zool. 53(2): 173-181.

Tengkano W \& Suharsono. 2005. Ulat grayak Spodoptera litura Fabricius (Lepidoptera: Noctuidae) pada tanaman kedelai dan pengendaliannya. Bul. Palawija. 52(10): 43-52.
Tian BI, Liu QZ, Liu ZL, Li P, \& Wang JW. 2015. Insecticidal potential of clove essential oil and its constituents on Cacopsylla chinensis (Hemiptera: Psyllidae) in laboratory and field. $J$. Econ. Entomol. 108(3): 957-961.

Vargas-Méndez LY, Sanabria-Flórez PL, SaavedraReyes LM, Merchan-Arenas DR, \& Kouznetsov VV. 2019. Bioactivity of semisynthetic eugenol derivatives against Spodoptera frugiperda (Lepidoptera: Noctuidae) larvae infesting maize in Colombia. Saudi J. Biol. Sci. 26(7): 16131620.

Waliwitiya R. 2005. Toxicities of thymol, citronellal, eugenol and rosemary oil to control Agriotes obscurus (Coleoptera: Elateridae) in laboratory and greenhouse bioassays. Theses. The University of British Columbia. 